\title{
Peluang Inovasi Produk Tas Wanita Berbahan Ulap Doyo Berdasarkan Preferensi Masyarakat Di Kalimantan Timur
}

\author{
Dita Andansari,,$^{*}$ Darius Shyafary ${ }^{2}$ \\ ${ }^{1,2}$ Program Studi Desain Produk, Jurusan Desain, Politeknik Negeri Samarinda, Samarinda, Indonesia
}

\begin{abstract}
Typical crafts in East Kalimantan consist of a wide variety of products, but craft products that are the flagship of one of them is Ulap Doyo fabric. Ulap Doyo has experienced development in its application, namely for fashion products such as clothing, but there are still few SMEs Ulap Doyo who do product development. Lately, product development is being heavily directed at a product designed based on customer-oriented needs. Product development can be done in every aspect of the product. Innovation / development of bags made from ulap doyo in East Kalimantan based on people's preferences with kansei engineering methods is still very limited, especially still in form only. It is necessary to examine the opportunity for innovation / development of women's handbags made from ulap doyo from design aspects other than form, from the aspect of function and aspects of manufacturability. The method used is a descriptive method with reference straightening. The results of this study are to show that the innovation of bag products made from ulap doyo in terms of product innovation based on people's preferences is still very likely because there is not much research that discusses based on preferences from the community. The conclusion of the study is the innovation of women's bags made from ulap doyo in terms of product innovation based on people's preferences that have been done in: $a$. four components of the bag, $b$. three combination materials, $c$. five functions of the bag.
\end{abstract}

Key words: opportunity, innovation, women's bag, ulap doyo, preferences, East Kalimantan

\begin{abstract}
Abstrak
Kerajinan khas di Kalimantan Timur terdiri dari berbagai macam produk, tetapi produk kerajinan yang merupakan unggulan salah satunya adalah kain Ulap Doyo. Ulap Doyo sudah mengalami perkembangan dalam aplikasinya yaitu untuk produk fesyen seperti pakaian, tetapi masih sedikit UKM Ulap Doyo yang melakukan pengembangan produknya. Akhir-akhir ini, pengembangan produk sedang banyak diarahkan pada suatu produk yang dirancang berdasarkan kebutuhan pelanggan (customer-oriented). Pengembangan produk bisa dilakukan pada setiap aspek produk. Inovasi/ pengembangan tas berbahan ulap doyo di Kalimantan Timur berdasarkan preferensi masyarakat dengan metode kansei engineering masih sangat terbatas terutama masih pada bentuk saja. Perlu dikaji peluang inovasi/ pengembangan tas tangan Wanita berbahan ulap doyo dari aspek desain selain bentuk, dari aspek fungsi serta aspek manufacturability. Metode yang digunakan adalah metode deskriptif dengan penelurusan referensi. Hasil dari penelitian ini adalah menunjukkan bahwa inovasi produk tas berbahan ulap doyo dari segi inovasi produk berdasarkan preferensi masyarakat masih sangat berpeluang karena belum banyak penelitian yang membahas berdasarkan preferensi dari masyarakat. Kesimpulan dari penelitian adalah inovasi tas wanita berbahan ulap doyo dari segi inovasi produk berdasarkan preferensi masyarakat yang telah dilakukan ada pada : a. empat komponen tas, b. tiga bahan kombinasi, c. lima fungsi tas.
\end{abstract}

Kata kunci: peluang, inovasi, tas wanita, ulap doyo, preferensi, Kalimantan Timur

\footnotetext{
* Corresponding author : ditaandansari@ polnes.ac.id
} 


\section{Pendahuluan}

Industri kreatif nasional pertumbuhannya mengalami peningkatan setiap tahunnya. Saat ini, peningkatan pertumbuhan industri kreatif nasional mencapai $7 \%$ (Husin, 2021). Tahun 2015 sampai sekarang kontribusi yang besar dari industri kreatif berperan dalam peningkatan produk domestik bruto (PDB) nasional, sejak munculnya di tahun 2007. Pada tahun 2015 tercatat Rp. 852 triliun kontribusi industri kreatif terhadap pendapatan domestik bruto (PDB) nasional dan pada tahun 2020 mencapai Rp. 1.100 triliun.

Penyumbang terbanyak PDB nasional adalah subsektor kerajinan, selanjutnya subsektor fashion dan disusul oleh subsektor periklanan. Sub sektor kerajinan dalam beberapa tahun belakangan tetap bertahan sebagai penyumbang terbanyak PDB nasional karena sumber daya alam pendukung untuk pembuatan kerajinan masih banyak tersedia. Sebagai calon ibukota baru di Kalimantan Timur, pertumbuhan industri kreatif juga mengalami peningkatan dan terdapat 4 subsektor yang kedepannya menjadi andalan karena diyakini akan berkembang yaitu arsitektur karena banyak pembangunan gedung-gedung terutama gedung perkantoran, desain interior sebagai pengisi ruang dalam dari bangunan gedung yang akan banyak dibuat, kuliner sebagai kebutuhan pokok yang semakin meningkat karena rencana kepindahan ibu kota serta subsektor yang terakhir adalah kerajinan. Nilai ekspor UKM Kalimantan Timur di tahun 2020 mencapai Rp. 428,2 miliar.Sub sektor kerajinan di Kalimantan Timur yang menembus ekspor meliputi olahan kayu, aksesoris manik, batu, kerajinan rotan dan Mandau. Menurut Noor (2021), industru kriya di Kalimantan Timur yang mempunyai potensi untuk dikembangkan adalah kerajinan berbasis tekstil, kulit, kayu, anyaman, kertas, kaca, logam, usaha mebel/furnitur, perhiasan dan barang berharga. Selain merambah ekspor, produk kriya UKM di Kalimantan Timur juga sukses di pasar dalam negeri diantaranya yaitu aksesoris manik-manik, batu, sarung Samarinda, anyaman manik, anyaman rotan, ulap doyo serta Mandau.Untuk kerajinan berbasis tekstil khas Kalimantan Timur yang sudah sangat berkembang saat ini diwakili oleh sarung Samarinda dan Ulap doyo. Sedangkan kerajinan berbasis tekstil lainnya yang sedang dikembangkan saat ini adalah batik Kalimantan Timur.

Kerajinan khas di Kalimantan Timur terdiri dari berbagai macam produk, tetapi produk kerajinan yang merupakan unggulan salah satunya adalah kain Ulap Doyo. (Ketua Dekranasda Kaltim, Amelia Suharni Faroek, 2014). Ulap Doyo sudah mengalami perkembangan dalam aplikasinya yaitu untuk produk fesyen seperti pakaian, tetapi masih sedikit UKM Ulap Doyo yang melakukan pengembangan produknya.

Menurut Menteri Perindustrian Airlangga Hartarto pada pembukaan Indonesia Fashion Week (IFW) 2017 di Jakarta, Rabu (1 Februauri 2017), bahwa Industri fesyen berkontribusi besar terhadap devisa negara, PDB nasional dan penyerapan tenaga kerja. Nilai ekspor produk fesyen pada tahun 2015 mencapai USD12,11 miliar, berdasarkan data BPS, dengan pasar utama Amerika Serikat, Eropa dan Jepang. Dan kontribusi industri fesyen terhadap PDB nasional sebesar 1,21 persen. Industri fesyen mampu menyerap tenaga kerja sebanyak dua juta orang atau 14,7 persen dari total tenaga kerja di sektor industry untuk sektor padat karya.

Transaksi tertinggi yang tercatat di aplikasi Shopee sebagai salah satu marketplace online adalah kategori belanja fashion. Menurut Chris Feng selaku CEO Shopee, di Fairmount Hotel, Jumat (19/1/2018), yang masuk dalam kategori fashion dengan transaksi tertinggi adalah busana, sepatu, dan pelengkap tampilan lainnya. Transaksi yang paling tinggi adalah kategori fashion yang diminati di Indonesia mencapai 400 ribu.

Seiring dengan perkembangannya, fashion tidak hanya didominasi oleh satu jenis produk yaitu pakaian saja, tetapi juga berkembang di dalamnya aksesoris seperti sepatu dan tas. Dari sejarah dapat dilihat, pada 1950an, ledakan ekonomi pascaperang memicu revolusi mode, dipelopori oleh Tampilan Baru Dior. Gaun dengan model pinggang yang pas, rok panjang menyerempet pergelangan kaki, dan wanita membutuhkan tas tangan yang lebih kecil dan terstruktur untuk menyeimbangkan siluet baru ini. Sementara pada tahun 1980-an, dengan gaya maksimalnya dan konsumerisme yang merajalela, merupakan masa kejayaan untuk fashion, dan tas tangan adalah cara tercepat untuk mengkomunikasikan gaya si pemiliknya [1]. Dari penjelasan di atas, maka tas wanita masih mempunyai peluang untuk dikembangkan sebagai salah produk aksesoris fesyen.

Menghadapi persaingan yang semakin ketat, para UKM dituntut untuk selalu meningkatkan kualitas dan selalu berpengembangan/berinovasi terhadap produknya. Beberapa penelitian sebelumnya yang telah dilakukan oleh pihak lain menyimpulkan bahwa pengembangan dapat meningkatkan kualitas dan nilai ekonomis sebuah produk serta pengembangan perusahaan tidak mempengaruhi kinerja perusahaan secara langsung, tapi berpengaruh signifikan terhadap kualitas produk. Adapun kualitas produk berpengaruh signifikan terhadap kinerja perusahaan.

Akhir-akhir ini, pengembangan produk sedang banyak diarahkan pada suatu produk yang dirancang berdasarkan kebutuhan pelanggan (customer-oriented) [2]. Perusahaan mencari lebih dalam keinginan dan 
kebutuhan pelanggan dan mengubahnya menjadi suatu produk yang berdaya guna. Pelanggan ketika memilih sebuah produk, tidak hanya berdasarkan alasan-alasan logis seperti fungsi produk atau harga, tetapi sampai kepada emosi dan perasaan ketika melihat, merasakan produk tersebut juga kemudian menjadi faktor penting dalam memilih produk. Faktor afektif dijelaskan sebagai emosi, perasaan dan keinginan serta hasrat tersembunyi dalam benak seseorang. Nagamachi memperkenalkan suatu metode yang disebut Kansei engineering untuk menterjemahkan faktor afektif pelanggan. Metode ini digunakan untuk menterjemahkan perasaan, emosi, dan impresi seseorang pada produk yang diinginkan [3]. Menurut Haryono dan Bariyah [4] dalam penelitian yang berjudul "Perancangan Konsep Produk Citra/image dan perasaan psikologi konsumen alas kaki dengan menggunakan Integrasi Metode Kansei Engineering dan Model Kano" menyimpulkan bahwa desain dua kategori Kano adalah desain yang sesuai, yaitu one-dimensional dan indifferent. Pada penelitian yang lain [5] dalam penelitian yang berjudul "Rancangan Konsep Produk Alat Makan Portable Menggunakan Metode Kansei Engineering" menyimpulkan bahwa alat makan yang dirancang dapat memuaskan konsumen saat membawa dan menggunakan produk tersebut. Penelitian lain yang berkaitan dengan pengembangan produk menggunakan metode kansei engineering seperti: jam meja dari bahan bambu [6], desain mantel [7], bahan furniture [8], desain kursi makan rotan [9], pengembangan metodologi affective design [10], desain kombinasi kuda goyang dan kursi lipat anak [11], desain produk apparel [12].

Supaya produk baru akan selalu laku di pasaran, maka dalam mengembangkan sebuah produk, maka kesukaan (preferensi) dari masyarakat pengguna harus diperhatikan dengan seksama. Penelitian yang berjudul $R e$ birthed fashion handbags as a collaborative design project, menghasilkan analisis desain yang menunjukkan bahwa desain yang tidak perlu diperhatikan karena terlalu umum atau tidak berbeda dari barang serupa lainnya sebagai alasan paling umum untuk tidak dipilihnya produk di pasar [13]. Dalam kasus seperti itu, konsumen dapat mengganti desain dasar ini dengan produk merek yang lebih murah. Karena itu, desain tas fashion yang dibuat kembali ditambah fitur desain yang unik dan utilitas sehingga dapat dikenali konsumen sebagai terkait dengan identitas merek [13]. Dari kesimpulan ini, terlihat bahwa fitur/ komponen produk merupakan salah satu hal penting dalam sebuah desain.

Penelitian sebelumnya oleh Andansari dan Keliwar [14] yang telah dilakukan untuk mengetahui preferensi masyarakat terhadap produk fesyen tas berbahan ulap doyo berdasarkan elemen produk. Adapun hasilnya (1) Faktor-faktor yang mempengaruhi preferensi masyarakat dalam memilih produk fashion tas dari bahan ulap doyo adalah faktor utama : Emotional Appeal dan Detil Desain dengan variansi sebesar 48,286\% serta faktor Gaya Desain dengan variansi sebesar 16,051\%. (2) Kansei Masyarakat terhadap produk fashion tas dari bahan ulap doyo adalah bangga, modis dan elegan, indah, nyaman, unik, alami dan Tradisional (3) Desain produk fashion tas dari bahan ulap doyo berdasarkan karakteristik desain yang diperoleh dari hasil penelitian adalah Desain Alternatif 1 dengan komposisi elemen produk pegangan ada ring, bagian penutup depan setengah, bagian kantong dengan ritsleting, bagian sambungan (gusset) yaitu sambungan dengan tali dan berkancing serta bahannya adalah gabungan kain tenun ulap doyo dan kulit asli.

Penelitian lanjutan yang dilakukan oleh Andansari dan Keliwar [15] pengembangan desain produk fesyen tas berbahan ulap doyo menggunakan prinsip komposisi desain berdasarkan preferensi masyarakat sehingga produk dapat meningkat penjualannya karena dibuat berdasarkan minat dari masyarakat. Dari analisis terhadap kuesione SD I, dimana konsumen diminta melakukan penilaian terhadap produk tas tangan wanita berbahan gabungan ulap doyo dan kulit asli, diketahui bahwa ada 4 faktor yang berpengaruh dalam memilih produk tas tangan wanita berbahan ulap doyo dan kulit asli, yaitu : emotional appeal dan dan desain, warna, detil desain dan bahan/bahan. Dari keempat factor tersebut, hasil output regresi linier berganda menunjukkan bahwa factor yang paling dominan dalam menggambarkan preferensi konsumen ialah emotional appeal dan desain. Tetapi pada analisis kuesioner SD II dimana konsumen diminta melakukan penilaian terhadap 11 sampel desain tas tangan wanita berbahan gabungan ulap doyo dan kulit asli diketahui bahwa faktor yang paling kuat yang mempengaruhi preferensi pelanggan dalam memilih adalah warna (cerah), sedangkan faktor emotional appeal dan desain menempati urutan kedua.

Perasaan pelanggan dalam memilih tas tangan wanita berbahan gabungan ulap doyo dan kulit asli ditentukan oleh bangga, indah, unik, nyaman, dominan etnik, bahan bertekstur, motif, elegan, cerah, ringan.

Dari hasil analisis kruskal wallis, didapatkan karakteristik desain tas tangan wanita berbahan gabungan ulap doyo dan kulit asli adalah :
1. Irama
:oposisi
2. Warna
: hangat
3. Keseimbangan
: simetris 

4. Dominan bahan : ulap doyo
5. Tekstur : halus
6. Jenis tas : : handled bag
7. Motif : bermotif
8. Dominan bentuk : lengkung

Pengembangan produk bisa dilakukan pada setiap aspek produk. Terdapat beberapa aspek produk seperti yang dijelaskan oleh IDSA (Industrial Designer Sociaty of America) bahwa desainer industri biasanya fokus pada penampilan fisik, fungsionalitas dan manufacturability suatu produk, meskipun mereka sering terlibat lebih banyak dalam siklus pengembangan. Penampilan fisik bisa dikaitkan dengan desain seperti bentuk, komponen, warna, bahan dan tekstur. Secara fungsi, fungsi tas bermacam-macam diantaranya tas untuk keperluan sekolah atau bekerja, tas santai atau tas jalan, tas untuk fesyen, tas untuk berbelanja dan masih banyak yang lainnya. Manufacturabilitydalam pembuatan tas bisa dengan manual, mesin ataupun gabungan dari keduanya manual dan mesin.

Inovasi/pengembangan tas berbahan ulap doyo di Kalimantan Timur berdasarkan preferensi masyarakat dengan metode kansei engineering masih sangat terbatas terutama masih pada bentuk saja. Perlu dikaji peluang inovasi/ pengembangan tas tangan Wanita berbahan ulap doyo dari aspek desain selain bentuk, dari aspek fungsi serta aspek manufacturability.

\section{Bahan dan Metode}

Obyek yang dibahas pada penelitian ini adalah produk tas dari bahan ulap doyo sebagai tekstil khas Kalimantan Timur. Metode yang digunakan adalah metode deskriptif dengan penelurusan referensi.

\section{Hasil dan Pembahasan}

Dalam pengembangan produk, pada strategi inovasi produk terdapat tiga hal inovasi yaitu inovasi produk, inovasi proses dan inovasi pemasaran. Pada penelitian ini, pembahasan berfokus pada inovasi produk dan lebih khususnya adalah produk tas dari bahan ulap doyo. Aspek produk yang akan dibahas adalah aspek penampilan fisik (desain), aspek fungsi dan aspek manufacturability. Aspek penampilan fisik (desain) yang akan dibahas meliputi komponen dan bahan. Pembahasan dilakukan dengan melihat peluang inovasi produk tas dari bahan ulap doyo dengan melihat penelitian yang sudah dilakukan sebelumnya baik oleh penulis sendiri maupun pihak lain, Komponen tas yang ada diantaranya adalah : pegangan tas, penutup tas, bentuk samping, bentuk ujung, bagian bawah, kantong, bagian dalam, gesper, kaitan, bingkai, sudut logam, rantai, payet dan manik, ritsleting, penarik ritsleting, kaki dasar, pengunci, bentuk pelat logam, hiasan dan aksesoris.

Bahan tas bisa mermacam-macam, dalam hal ini adalah bahan gabungan selain bahan utama adalah ulap doyo. Bahan penunjang tersebut bisa kulit asli, kulit sintetis maupun jenis kain baik kain khas Kaltim seperti sarung samarinda atau jenis kain pada umumnya seperti kain kanvas, denim, suede, cordura, ripstop nylon dan katun. Fungsi tas ada beberapa diantaranya adalah pouch, clutch, minaudi'ere, wristlet, box bag, handhled bag, shopper bag, tote bag, satchel, crossbody bag, camera bag, one strap bookbag, belt bag, waist pack, backpack, cosmetic bag, sports duffel bag, bowling bag, messenger bag dan laptop bag. Proses produksi untuk pembuatan tas bisa dilakukan dengan 2 cara yaitu manual dan mesin.

Berikut ini adalah peluang inovasi produk tas dari bahan ulap doyo dilihat dari inovasi yang sudah dilakukan pada penelitian terdahulu.

a. Pengembangan Desain Produk Fesyen Berbahan Ulap Doyo untuk diaplikasikan di UKM Pokant Takaq, Tenggarong, Kalimantan Timur Guna Mendukung Sektor Pariwisata [14].

Komponen Tas (Dipilih berdasarkan preferensi pengguna): Pegangan, Bagian penutup, Bagian kantong, Bagian samping,

Bahan Tas (Dipilih berdasarkan preferensi pengguna): Kulit asli, Kulit Sintetis, Kanvas

$\begin{array}{ll}\text { Fungsi } & : \text { Handhled bag } \\ \text { Proses Produksi } & \text { : Jahit masinal }\end{array}$


b. Pengembangan Desain Produk Tas Wanita Berbahan Ulap Doyo Menggunakan Prinsip Komposisi Desain Guna Mendukung Sektor Pariwisata Di Kalimantan Timur [15].

Komponen Tas (Dipilih berdasarkan preferensi pengguna): Pegangan, Bagian penutup, Bagian kantong, Bagian samping,

Bahan Tas (Dipilih berdasarkan preferensi pengguna): Kulit asli

Fungsi $\quad$ : Handhled bag, Tote bag

Proses Produksi : Jahit masinal

c. Desain Tas Ransel Remaja Wanita Dengan Kombinasi Kulit Dan Tenun Ulap Doyo Khas Kalimantan Timur (Yasmin, 2021)

Komponen Tas (Dipilih berdasarkan analisis desainer): Pegangan tas, Penutup tas, Kantong, Bagian dalam, Gesper, Kaitan, Kuncian, Ritsleting

Bahan Tas (Dipilih berdasarkan analisis desainer): Kulit asli

Fungsi : Backpack

Proses Produksi : Jahit masinal

d. Desain Tas Kasual Dari Kanvas Beraksen Ulap Doyo Untuk Remaja Laki-Laki [16].

Komponen Tas: Tidak dibahas

Bahan Tas (Dipilih berdasarkan analisis desainer): Kain kanvas

Fungsi $\quad$ : Cross body backpack

Proses Produksi : Jahit masinal

e. Desain Tas Selempang Berbahan Ulap Doyo,Kulit Dan Kayu Khas Kalimantan [17].

Komponen Tas (Dipilih berdasarkan preferensi pengguna): Pegangan, Kuncian, Gesper, Kaitan

Bahan Tas (Dipilih berdasarkan analisis desainer): kulit asli dan Kayu meranti

Fungsi $\quad$ : Sling bag

Proses Produksi : Jahit manual

f. Desain Tas Selempang Ulap Doyo Dengan Kombinasi Kulit Dilengkapi Dengan Tempat Alat Kesehatan Covid-19 [18].

Komponen Tas (Dipilih berdasarkan preferensi pengguna): Pegangan

Komponen Tas (Dipilih berdasarkan analisis desainer): Penutup tas, Kantong, Bagian dalam, Gesper, Pengait, Ritsleting

Bahan Tas (Dipilih berdasarkan analisis desainer): kulit asli

Fungsi : Sling bag

Proses Produksi : Jahit masinal 
Tabel di atas menunjukkan bahwa inovasi produk tas berbahan ulap doyo dari segi inovasi produk berdasarkan preferensi masyarakat masih sangat berpeluang karena belum banyak penelitian yang membahas berdasarkan preferensi dari masyarakat.

\section{Kesimpulan}

Inovasi tas wanita berbahan ulap doyo dari segi inovasi produk berdasarkan preferensi masyarakat yang telah dilakukan ada pada :

- komponen tas (pegangan, bagian penutup, bagian kantong dan bagian samping),

- bahan kombinasi (kulit asli, kulit sintetis, knvas),

- fungsi tas (Handhled bag, Tote bag, Backpack, Cross body backpack dan Sling bag)

Sehingga peluang inovasi produk tas ulap doyo dari segi inovasi produk berdasarkan preferensi masyarakat bisa dilakukan pada :

- komponen tas : bentuk ujung, bagian bawah, bagian dalam, bingkai, sudut, logam, rantai, payet dan manik, ritsleting, penarik ritsleting, kaki dasar, bentuk pelat logam, hiasan dan aksesoris.

- Bahan kombinasi : kain khas Kaltim seperti sarung samarinda atau kain umum seperti denim, suede, cordura, ripstop nylon dan katun

- Fungsi tas : pouch, clutch, minaudi'ere, wristlet, box bag, shopper bag, satchel, crossbody bag, camera bag, one strap bookbag, belt bag, waist pack, cosmetic bag, sports duffel bag, bowling bag, messenger bag dan laptop bag.

Selain komponen tas, bahan kombinasi dan fungsi tas, maka inovasi produk tas berbahan ulap doyo berdasarkan preferensi masyarakat pengguna bisa juga dilakukan dari segi komposisi desain. 


\section{Daftar pustaka}

[1] "bag trends by the decade." https://www.vogue.co.uk/gallery/bag-trends-by-the-decade (accessed.

[2] Y. O. Nagamachi M. and M.Ishikawa, "Kansei Engineering and application of the rough sets model," Proc.IMechE Vol220 Part I:J. Systems and Control Engineering., 2006.

[3] M. Nagamachi, Kansei/Affective Engineering. Boca Raton: Taylor \& Francis Group, 2011.

[4] M. Haryono and Bariyah, "Perancangan Konsep Produk Alas Kaki dengan Menggunakan Integrasi Metode Kansei Engineering dan Model Kano," Jurnal Ilmiah Teknik Industri, vol. 13, 1, p. 12, 2014.

[5] Desrianty and Widyani, " Rancangan Konsep Produk Alat Makan Portable Menggunakan Metode Kansei Engineering. ," Journal Industrial Servicess vol. 3, 1, Oktober 20172017.

[6] A. Shergian and I. T, "Design of Innovative Alarm Clock Made From Bamboo With Kansei Engineering Approach," Agriculture and Agricultural Science Procedia, vol. 3, p. 5, 2014.

[7] H. Quan, "Product Innovation Design Based on Deep Learning and Kansei Engineering," Applied Sciences 2018.

[8] Q. Lei, et all,, "Study on the Materials Design of Furniture Based on Kansei Engineering," International Journal of Engineering Innovation \& Research, vol. 4, no. 5, 2015.

[9] V. S. Johan, et all, "Identifikasi Kansei Untuk Evaluasi Desain Produk Kursi Makan Rotan Kansei Identification For Rattan Dining Chair Design Evaluation. ," Jurnal Inovisi ${ }^{\text {TM }}$ vol. 7, 2, Oktober 20112011.

[10] M. Hartono, "Kansei mining-based in services sebagai alternatif pengembanga nmetodologi affective design," KELUWIH: Jurnal Sains dan Teknologi, vol. 1, 1, p. 6, Februari 20202020.

[11] I. Prakoso and H. Purnomo, "Innovative Design of the Combined Rocking Horse Toy and Folding Chair for Children," International Journal on Advanced Science Engineering Information Technology, vol. 9, 2019.

[12] J. Rajasekera, "Apparel Design Optimization for Global Market : Kansei Engineering Preference Model," International Journal of Affective Engineering March 20152015.

[13] Lee and DeLong, "Re birthed fashion handbags as a collaborative design project," Springer Nature, 28 May 2018. 2018.

[14] Andansari and Keliwar, "The Development of Ulap Doyo Handheld Handbag For Application in Pokant Takaq Small and Medium Enterprise, Kalimantan Timur To Support Tourism Sector," presented at the The 4th International Conference on Applied Science and Technology (iCAST 2021), Samarinda, 2019.

[15] Andansari and Keliwar, "Kansei Factor in Developing Design Of Women's Bag Materials Of Combination of Doyo Woven Fabric and Genuine Leather," in Borobudur International Symposium on Humanities and Social Sciences, Magelang, 2020, vol. 2.

[16] A. Rahmitasari, "Desain Tas Kasual Dari Kanvas Beraksen Ulap Doyo Untuk Remaja Laki-Laki," 2021.

[17] E. Nofiansyah, "Desain Tas Selempang Berbahan Ulap Doyo, Kulit Dan Kayu Khas Kalimantan.," 2021.

[18] Y. Dianita, "Desain Tas Selempang Ulap Doyo Dengan Kombinasi Kulit Dilengkapi Dengan Tempat Alat Kesehatan Covid-19," 2021. 